\title{
All trans-retinoic acid acts synergistically with hydroxytamoxifen and transforming-growth factor $\beta$ to stimulate apoptosis in MCF-7 breast cancer cells
}

\author{
D N Danforth Jr
}

Surgery Branch, National Cancer Institute, National Institutes of Health, Bldg. 10/Rm 2B42, Bethesda, Maryland 20892, USA

(Requests for offprints should be addressed to the author; Email: David_Danforth@nih.gov)

\begin{abstract}
The anti-estrogen 4-hydroxytamoxifen (TAM) and vitamin A-related compounds, the retinoids, in combination act synergistically to inhibit growth of breast cancer cells in vitro and in vivo. To clarify the mechanism of this synergism, the effect of TAM and all trans-retinoic acid (AT) on proliferation of MCF-7 breast cancer cells was studied in vitro. TAM and AT acted synergistically to cause a time-dependent and dose-dependent inhibition of MCF-7 cell growth. In a temporally related manner, TAM+AT acted synergistically to downregulate Bcl-2 mRNA and Bcl-2 protein expression, and to stimulate apoptosis. TAM and AT each blocked cell cycle progression throughout 7 days of treatment but without any synergistic or additive effect on this process, indicating a selective synergism for apoptosis.

The negative growth factor-transforming growth factor $\beta$ (TGF $\beta$ ) is secreted by these cells and was studied as a potential mediator of the synergistic effects of TAM+AT
\end{abstract}

on apoptosis. TAM+AT acted synergistically to induce a fivefold increase in TGF $\beta 1$ secretion over $72 \mathrm{~h}$. TGF $\beta 1$ alone had no apoptotic effects on these cells; however, TGF $\beta 1$ in combination with AT acted synergistically to inhibit growth, to downregulate $\mathrm{Bcl}-2$ mRNA and Bcl-2 protein expression, and to stimulate apoptosis of these cells in a manner comparable with that noted for TAM+AT. The synergism of both TAM+AT and TGF $\beta 1+\mathrm{AT}$ for apoptosis was suppressed by estradiol. Co-incubation of TAM+AT with anti-TGF $\beta$ antibody did not block downregulation of $\mathrm{Bcl}-2$ protein expression or stimulation of apoptosis. The synergistic effects of TAM+AT on apoptosis therefore occur independently of TGF $\beta$, although TGF $\beta$ may interact with AT in a novel manner to provide another important anti-proliferative mechanism for breast cancer cells.

Journal of Endocrinology (2004) 183, 395-404

\section{Introduction}

The anti-estrogen tamoxifen (TAM) and vitamin A-related compounds, the retinoids, in combination act synergistically to inhibit growth of breast cancer cells. TAM acts additively/synergistically with all trans-retinoic acid (AT) (Wetherall \& Taylor 1986, Fontana 1987, Koga \& Sutherland 1991) or 4-hydroxyphenylretinide (fenretinide (Coradini et al. 1997)) to inhibit growth of estrogen receptor (ER)-positive breast cancer cells in vitro. In vivo, TAM acts synergistically with either 9-cis-retinoic acid or AT (Anzano et al. 1994) to reduce tumor number and tumor burden, and acts synergistically with fenretinide to prevent development, prevent recurrence following excision, and reduce the incidence and number of nitrosomethylurea-induced tumors in rats (Ratko et al. 1989). Clinically, TAM plays a major role in the prevention and treatment of breast cancer (Early Breast Cancer Trialists' Collaborative Group 1992, Fisher et al. 1998), encouraging the development of means for further enhancing its activity.

The mechanism of the synergistic action of antiestrogens and retinoids in combination on breast cancer cells is not known; however, there are important similarities in the actions of these agents. Both retinoids and anti-estrogens block cell cycle progression at $G_{0} G_{1}$, and both agents reduce the hyperphosphorylated form of the retinoblastoma protein $(\mathrm{pRb})$, indicating an important convergence point for their action (Wilcken et al. 1996). Both retinoids and anti-estrogens downregulate Bcl-2 gene and protein expression (Wang \& Phang 1995, Zhang et al. 1999) and stimulate apoptosis in breast cancer cells (Perry et al. 1995, Chen et al. 1996, Liu et al. 1996, Toma et al. 1997). These similarities raise the possibility that synergism involves shared anti-proliferative pathways. In addition, there is evidence to suggest that enhancement may be mediated through interaction of one or both of these agents with endogenous growth-inhibitory 
substances. The negative growth factor, transforminggrowth factor $\beta$ (TGF $\beta$ ), is secreted by these cells, and in turn can act in an autocrine manner on breast cancer cells to inhibit growth (Danforth \& Sgagias 1996, Perry et al. 1995). Importantly, it has been shown that exogenous TGF $\beta$ can interact with AT to inhibit growth of breast cancer cells as well as other cell types. Valette \& Botanch (1990) demonstrated that AT $(1 \mu \mathrm{M})$ and TGF $\beta(10 \mathrm{pM})$, in combination, acted synergistically to inhibit MCF-7 cell growth in a time- and dose-dependent manner over 6 days in culture. Others have shown that AT in combination with TGF $\beta$ acts additively/synergistically to inhibit growth of colon cancer cells (Hoosein et al. 1988), glioblastoma cells (Helseth et al. 1988), and epidermal keratinocytes (Tong et al. 1990). It is well known that TAM acts on breast cancer cells to stimulate secretion of TGF $\beta$ (Knabbe et al. 1987, Perry et al. 1995). These findings raise the intriguing possibility that TGF $\beta$ may interact with AT to mediate the synergism of AT with TAM. To clarify the mechanism of synergy between TAM and retinoids, the anti-proliferative effects of TAM and AT on MCF-7 human breast cancer cells were studied in vitro. These studies indicate that AT acts synergistically with both TAM and TGF $\beta$ to stimulate apoptosis in these cells; however, these two processes appear to act independently.

\section{Materials and Methods}

\section{Chemicals}

AT, TAM, 17 $\beta$-estradiol, leupeptin, and aprotinin were purchased from Sigma Corporation, St Louis, MO, USA. Monoclonal antibody to Bcl-2 protein was obtained from Calbiochem, San Diego, CA, USA. Recombinant human TGF $\beta 1$ (rhTGF $\beta$ ), anti-TGF $\beta$ neutralizing antibody (no. AB-100-NA), and ELISA for detection of TGF $\beta 1$ and TGF2 were obtained from R \& D Systems, Minneapolis, MN, USA.

\section{Cell line and cell culture}

MCF-7 human breast cancer cells were obtained from the Michigan Cancer Foundation, Detroit, MI, USA. Cell cultures were maintained in Costar flasks with Improved Minimum Essential Medium (IMEM) supplemented with $5 \%$ heat-inactivated fetal calf serum (FCS; Biofluids Inc., Rockville, MD, USA), glutamine (2 $\mathrm{mM})$, and gentamicin $(40 \mathrm{mg} / \mathrm{l})$. The FCS, unless indicated, did not undergo processing to remove endogenous steroids, in agreement with previous studies (Marth et al. 1984, Fontana 1987, Koga \& Sutherland 1991, Butler \& Fontana 1992, Koli et al. 1997, Ko et al. 1998, Wu et al. 1998). For studies evaluating estradiol, cells were plated in phenol red-free IMEM supplemented with heat-inactivated FCS stripped of endogenous steroids by charcoal. After $48 \mathrm{~h}$ the medium was replaced with fresh medium containing added substances as indicated in the figure legends. All steroids for experimental studies were diluted from 1000-fold stock concentrates. Ethanol carrier was added to control media; final ethanol content of media was $<0 \cdot 1 \%$. For cell growth studies evaluating TGF $\beta$, $\operatorname{rhTGF} \beta 1$ (no. $240-\mathrm{B}$; R \& D Systems, Minneapolis, MN, USA) was used. For cell counts, cells were harvested in dilute trypsin-EDTA and counted in isotone in a Coulter counter (Coulter Electronics, Hialeah, FL, USA). The doubling time for cell growth was calculated from the slope of a regression line fitted to the time course for each treatment group (Hayflick 1973). The additive or synergistic interaction of test substances on cell growth in combination was determined from the following formula (Berenbaum 1981, Koga \& Sutherland 1991): $(\mathrm{Ac} / \mathrm{Ae})+(\mathrm{Bc} / \mathrm{Be})=1$, where $\mathrm{Ae}$ and $\mathrm{Be}$ are doses of $\mathrm{A}$ and $\mathrm{B}$ alone that produce some specified growth-inhibitory effect, and Ac and Bc are their doses in combination that also have this same inhibitory effect. Values $<1$ indicate synergism, values $=1$ indicate additive effects, and values $>1$ indicate antagonism.

\section{Quantitative analysis of apoptosis}

Quantitative detection of cytoplasmic histoneassociated DNA fragments Cells $\left(1 \times 10^{5}\right)$ from control or treatment groups were lysed, centrifuged at $20000 \mathrm{~g}$, and the supernatant assayed for DNA fragments by the Cell Death ELISA (Roche Diagnostics Corp., Indianapolis, IN, USA) according to the manufacturer's instructions.

\section{Quantitative determination of DNA strand breaks} Detection and quantitation of apoptosis was determined by a two-color staining method which labels DNA breaks and total DNA. This was performed with the APO-BRDU kit (Pharmingen, San Diego, CA, USA) according to the manufacturer's instructions. Briefly, a monolayer of cells was harvested in PBS $/ 0.04 \%$ EDTA, fixed in $1 \%$ paraformaldehyde $\left(4{ }^{\circ} \mathrm{C}\right.$ for $15 \mathrm{~min}$ ), followed by $70 \%$ ethanol $\left(-20{ }^{\circ} \mathrm{C}\right.$ overnight). Cells were washed and recovered in FACS buffer (PBS/ $0.5 \%$ bovine serum albumin $/ 0.02 \%$ sodium azide). Cells were then labeled with bromolated deoxyuridine triphosphates (Br-dUTP) for $60 \mathrm{~min}$ at $37^{\circ}$ $\mathrm{C}$, stained with FITC (30 $\mathrm{min}$ at room temperature), and labeled with propidium iodine/RNAase solution. Flow cytometry of apoptotic cells and cell cycle analysis were performed using a Becton-Dickinson FACSCAN equipped with $488 \mathrm{nM}$ argon laser, and the Cell Quest computer program (Bectin-Dickinson Corp., San Jose, CA, USA).

\section{Immunoblotting}

Cell pellets from control or treatment groups were lysed in 2 volumes lysis buffer (Tris, $10 \mathrm{mM}, \mathrm{pH} 7 \cdot 4 ; \mathrm{NaCl}$, 
$150 \mathrm{mM}$; EDTA, $5 \mathrm{mM}$; 1\% Triton-X100, leupeptin and aprotinin, $0.5 \mu \mathrm{g} / \mathrm{ml}$ each and $1 \mathrm{mM}$ phenylmethylsulfonyl fluoride (Keane et al. 1996)). Cell lysates were centrifuged at $10000 \mathrm{~g}$, and $30 \mu \mathrm{g}$ total protein fractionated on $16 \%$ Tris/glycine/SDS gels (Invitrogen Corp., Carlsbad, CA, USA). Proteins were electrophoretically transferred to nitrocellulose, blocked with 5\% non-fat dry milk, probed with anti-Bcl-2 monoclonal antibody (1-2 $\mu \mathrm{g} / \mathrm{ml}$ PBS $/ 0 \cdot 05 \%$ Tween) washed, complexed with secondary horseradish peroxidase antibody and developed with ECL detection reagents (Santa Cruz Biotechnology, Inc., Santa Cruz, CA, USA). The membranes were stripped with $\mathrm{PBS} / 0 \cdot 1 \%$ Tween-20, reblocked and reprobed with anti- $\beta$ actin antibody (1:2000 dilution) as above. X-ray films were examined by densitometry and images quantitated using an Adobe Photoshop imager (Adobe Systems Inc., San Jose, CA, USA) and IP Labgel (Scanalytics Inc., Fairfax, VA, USA). The following densitometric ratio was calculated for each image: Densitometric ratio $=($ treatment $/$ actin $) /($ control $/$ actin $)$.

\section{$R N A$ extraction, $c D N A$ synthesis, and quantitative RT-PCR}

Cell monolayers of control or treatment groups were harvested in Hanks' balanced salt solution with a cell scraper, and total RNA was extracted from cell pellets with Trizol reagent (Invitrogen Corp.) according to the manufacturer's instructions. Total RNA was quantitated by spectrophotometry and stored at $-70{ }^{\circ} \mathrm{C}$ until assay.

cDNA synthesis was performed on total RNA with the Superscript First-Strand Synthesis System for RT-PCR (Invitrogen Corp.) according to the manufacturer's instructions. Three hundred nanograms of total RNA and $150 \mathrm{ng} / \mathrm{ml}$ of random hexamers were used for each synthesis. Each experiment included a no-reverse transcriptase control. Final cDNA preparations were treated with RNase $\mathrm{H}\left(37^{\circ} \mathrm{C}\right.$ for $\left.30 \mathrm{~min}\right)$ and stored at $-20^{\circ} \mathrm{C}$ until assay.

Quantitative RT-PCR was carried out on the ABI Prism 7700 Sequence Detector Thermal Cycler (Applied Biosystems, Foster City, CA, USA). Bcl-2 expression was detected using a predeveloped primer and probe set (Assays-on-Demand; Applied Biosystems). The probe contained a 6-carboxyfluorescein (FAM) reporter dye at the $5^{\prime}$ end and 6-carboxytetramethylrhodamine (TAMRA) quencher dye at the $3^{\prime}$ end. Each reaction mixture consisted of $25 \mu \mathrm{l}$ TaqMan Universal PCR Master Mix (Applied Biosystems, Foster City, CA, USA), 2.5 $\mu \mathrm{l}$ Assays-on-Demand gene expression assay mix, and $22.5 \mu \mathrm{l} \mathrm{H}_{2} \mathrm{O}$ containing $300 \mathrm{ng}$ cDNA equivalents. Glyceraldehyde-3-phosphate dehydrogenase (GAPDH) served as endogenous standard. PCR reactions were performed in 96-well optical reaction plates. Cycling conditions were $95{ }^{\circ} \mathrm{C} \times 10 \mathrm{~min}$ for denaturation, followed by 40 cycles of amplification at $15 \mathrm{~s}$ at $95^{\circ} \mathrm{C}$ and $1 \mathrm{~min}$ at $60{ }^{\circ} \mathrm{C}$. The threshold cycle was measured for each reaction.
Quantitation of RNA expression was determined by the method of Jeyaseelan et al. (2001), which calculates the ratio between the expression of $\mathrm{Bcl}-2$ to the expression of GAPDH in the calibrator and in the probe. Untreated MCF-7 cells served as the calibrator. A calibration curve was constructed over an input range of cDNA from 3 to $3000 \mathrm{ng}$. The amplification of the cDNA was linear over this range.

\section{TGF $\beta$ studies}

Isometric TGF $\beta 1$ and TGF $\beta 2$ concentrations of the cell monolayer media were determined by their respective ELISAs (R \& D Systems, Minneapolis, MN, USA). Briefly, MCF-7 cells were plated in IMEM supplemented with glutamine $(2 \mathrm{mM})$, and 5\% FCS stripped of endogenous steroids with dextran-coated charcoal. After $48 \mathrm{~h}$, the monolayers were washed twice with warm PBS and changed to serum-free IMEM supplemented with transferrin $(2 \mu \mathrm{g} / \mathrm{ml})$ to which test substances were added (Arteaga et al. 1993). After the incubation times indicated in the Figures, the medium was collected, leupeptin $(1 \mu \mathrm{g} / \mathrm{ml})$ and aprotinin $(1 \mu \mathrm{g} / \mathrm{ml})$ added, and samples either assayed immediately or stored at $-70{ }^{\circ} \mathrm{C}$. At the time of assay, samples were acid activated to $\mathrm{pH} 1.5$ with 1.0 M HCI, neutralized with $\mathrm{NaOH} / \mathrm{HEPES}$ to $\mathrm{pH} 7 \cdot 4$, and assayed for TGF $\beta 1$ and TGF $\beta$ by the ELISA specific for the respective isomeric TGF $\beta 2$ according to the manufacturer's instructions. There was no cross-reactivity between ELISAs for the alternate isomeric forms. All TGF $\beta$ concentrations were expressed as $\mathrm{pg} / 10^{6}$ cells of the feeder monolayer.

TGF $\beta$ neutralization studies were conducted using an anti-TGF $\beta$ antibody (no. AB-100-NA; R \& D Systems, Milwaukee, WI, USA). This antibody completely neutralizes the activity of TGF $\beta 1$, TGF $\beta 2$, and TGF $\beta 3$ isomeric forms, as determined by the manufacturer. A concentration $(20 \mu \mathrm{g} / \mathrm{ml})$ was selected which completely neutralized $300 \mathrm{pg} / \mathrm{ml}$ active exogenous rhTGF $\beta 1$ in IMEM supplemented with 5\% unstripped FCS (growth inhibition over 7 days: control/normal rabbit IgG/TGF $\beta 1,28 \cdot 9 \pm$ 3.5\%; anti-TGF $\beta$ antibody/TGF $\beta 1,0 \cdot 3 \pm 2 \cdot 4 \% ; P<0 \cdot 01$ ). Cell monolayers were incubated with media containing test substances and anti-TGF $\beta$ antibody $(20 \mu \mathrm{g} / \mathrm{ml})$ or a control normal IgG antibody, and $\mathrm{Bcl}-2$ protein expression or apoptosis measured as indicated in the figure legends.

\section{Statistical methods}

Statistical comparisons were analyzed by Kruskal-Wallis non-parametric comparisons of the means or Student's $t$-test using StatView statistical software (SAS Institute Inc., Cary, NC, USA). Data points represent the means \pm S.E.M. for three to four experiments unless stated otherwise. 


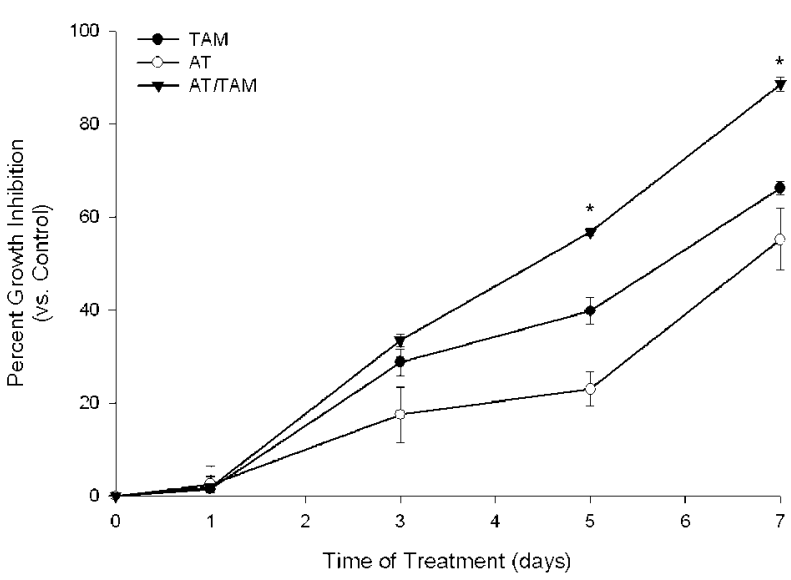

Figure 1 Inhibition of MCF-7 cell growth by TAM and AT. A monolayer of cells was incubated with vehicle or TAM (100 nM) and/or AT $(1 \mu \mathrm{M})$ and cell numbers determined at the indicated time points. Cell growth is expressed as the percent inhibition from control. ${ }^{*} P<0.05$ vs TAM or AT at day 5 or day 7 .

\section{Results}

Growth inhibition of MCF-7 cells by TAM and AT

AT and TAM in combination acted synergistically in a time-dependent manner to inhibit MCF-7 cell growth (Fig. 1). The synergy was dose dependent: at TAM= $100 \mathrm{nM}$, synergism was seen at $\mathrm{AT}=10^{-6} \mathrm{M}$ to $10^{-7} \mathrm{M}$ $(P<0 \cdot 05)$. At $\mathrm{TAM}=10 \mathrm{nM}$, synergistic effects were noted at $\mathrm{AT}=10^{-6} \mathrm{M}$ to $10^{-8} \mathrm{M}(P<0 \cdot 05)$, and at $\mathrm{AT}=10^{-8} \mathrm{M}$, synergism was noted at $\mathrm{TAM}=0 \cdot 10 \mathrm{nM}$ to $10 \cdot 0 \mathrm{nM}(P<0 \cdot 05)$. Doubling times were calculated from the time courses using $\mathrm{TAM}=100 \mathrm{nM}$ and $\mathrm{AT}=1 \mu \mathrm{M}$, and were as follows: control, $1 \cdot 75 \pm 0 \cdot 1$ days; TAM, $2 \cdot 86 \pm 0 \cdot 4$; AT, $2 \cdot 64 \pm 0 \cdot 5$; TAM + AT, $4 \cdot 7 \pm 0 \cdot 5)$. Synergy was confirmed by the method of Berenbaum (1981), which revealed a ratio of 0.02 at concentrations for each agent which provided for growth inhibition of approximately $50 \cdot 0 \%$.

Effect of TAM and AT on apoptosis, cell cycle progression, and cell differentiation

To determine if the synergistic inhibition of growth was due to the stimulation of apoptosis, the effect of AT+TAM on DNA fragmentation was studied at 4 days and 7 days of treatment. As shown in Fig. 2, at 7 days of treatment, TAM and AT acted synergistically to stimulate apoptosis three- to fourfold over control cells. This was confirmed by an alternative method which measured Br-dUTPlabeled DNA strand breaks. The spontaneous apoptotic rate in untreated cells by this method was approximately $1-2 \%$. At 7 days of treatment, TAM and AT in combination acted synergistically to stimulate apoptosis (Table 1), in agreement with the findings by the DNA fragmentation assay.

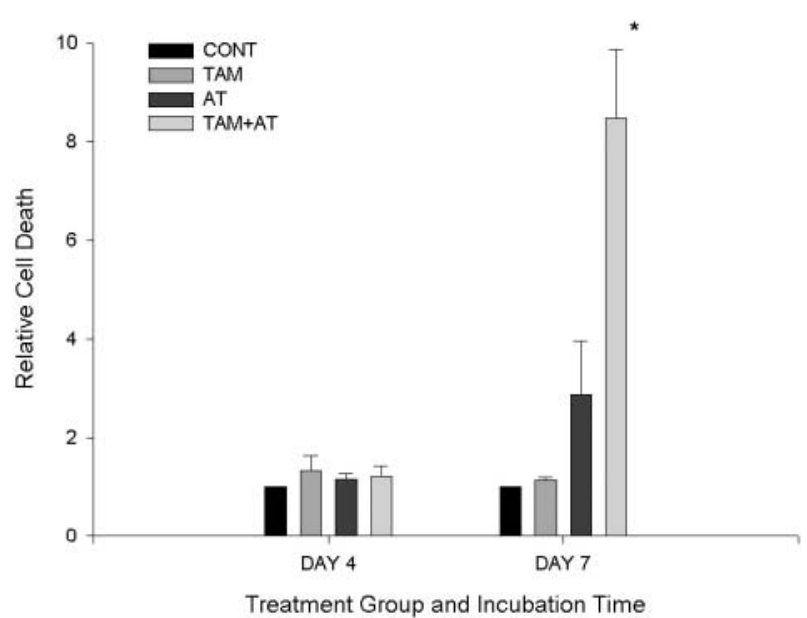

Figure 2 Stimulation of apoptosis by TAM and AT. Cells were incubated with vehicle (CONT) or TAM (100 nM) and/or AT $(1 \mu \mathrm{M})$ and apoptosis determined by DNA fragmentation ELISA on day 4 or day 7 as described in Materials and Methods. Values are expressed relative to control which is set to 1 at day 4 and day 7 . ${ }^{*} P<0 \cdot 01$ vs CONT, AT, TAM, day 7.

To further define regulation of apoptosis by TAM+AT, the effects of these agents on expression of the antiapoptotic protein $\mathrm{Bcl}-2$ was studied by immunoblot. This showed that, at 4 days, TAM+AT acted synergistically to downregulate $\mathrm{Bcl}-2$ protein expression, and these effects persisted through 7 days of treatment (Fig. 3). When the effects on Bcl-2 mRNA at $72 \mathrm{~h}$ was studied by quantitative RT-PCR, the combination of TAM+AT acted synergistically to downregulate Bcl-2 mRNA levels (Fig. 4). No cDNA synthesis was noted in the reaction which lacked reverse transcriptase, and cDNA synthesis was linear over an mRNA input range of 3-3000 ng.

Table 1 Stimulation of apoptosis by TAM and AT. A monolayer of cells was incubated with vehicle or TAM (100 nM) and/or AT $(1 \mu \mathrm{M})$ and percentage of total cells undergoing apoptosis determined by the APO-BRDU method on day 4 or day 7 as described in Materials and Methods

\section{Incidence of apoptosis (\%)}

$\begin{array}{ll}\text { Treatment group } & \\ \text { Day } 4 & \\ \text { Control } & 1 \cdot 3 \pm 0 \cdot 3 \\ \text { TAM } & 1 \cdot 7 \pm 0 \cdot 7 \\ \text { AT } & 3 \cdot 0 \pm 2 \cdot 0 \\ \text { TAM/AT } & 2 \cdot 7 \pm 1 \cdot 7 \\ \text { Day } 7 & \\ \text { Control } & 2 \cdot 5 \pm 1 \cdot 0 \\ \text { TAM } & 29 \cdot 4 \pm 8 \cdot 9 \\ \text { AT } & 24 \cdot 8 \pm 7 \cdot 6 \\ \text { TAM/AT } & 69 \cdot 1 \pm 9 \cdot 5^{*}\end{array}$

${ }^{*} P<0.05$ vs control, TAM, AT at day 7 . 


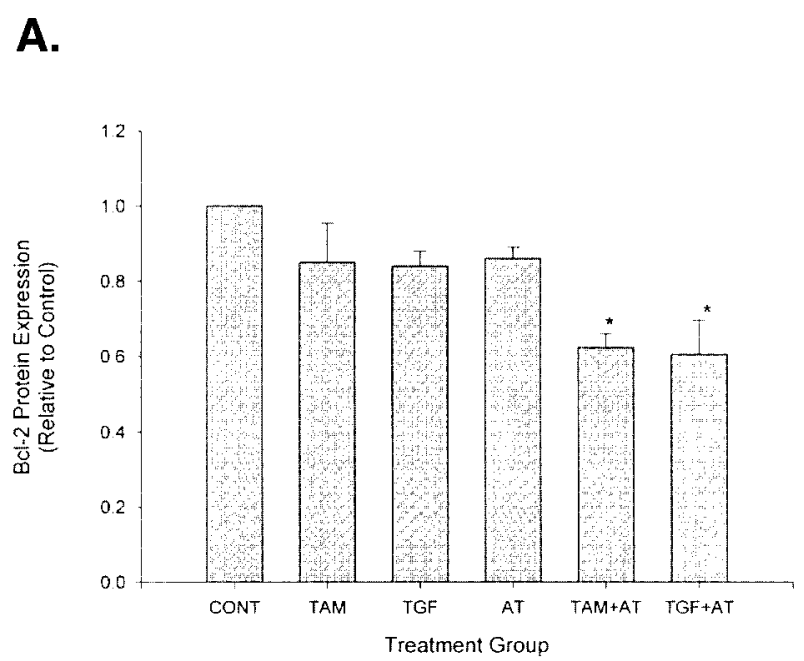

B.

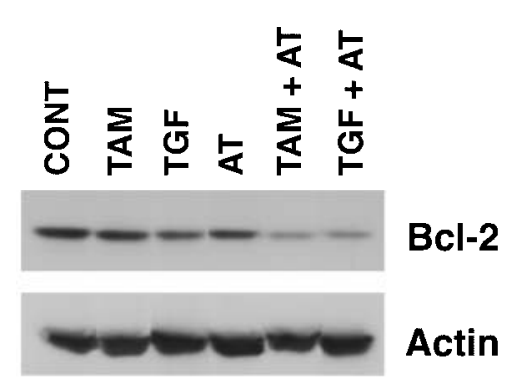

A.

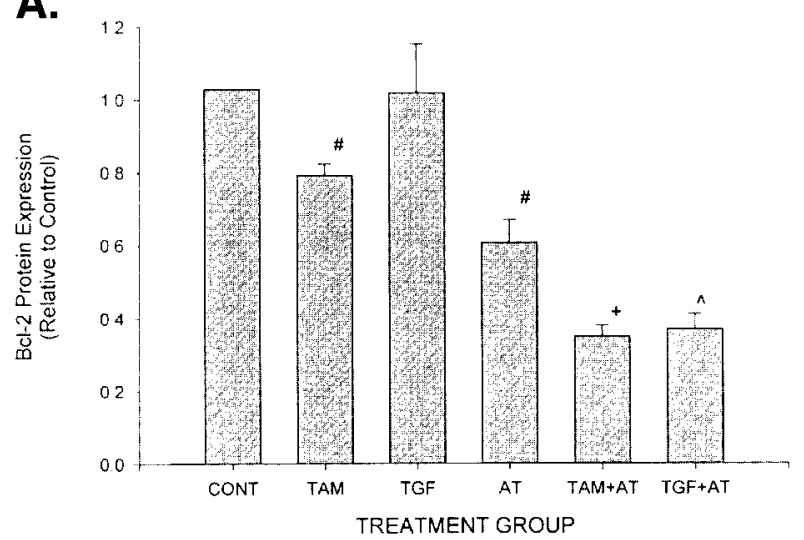

B.

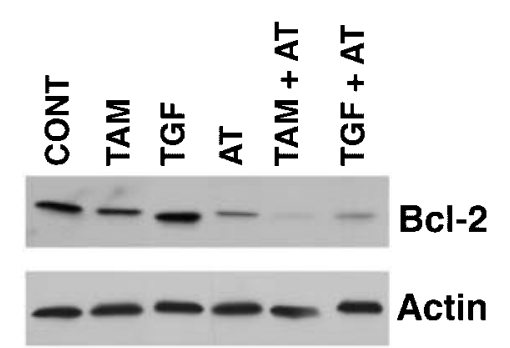

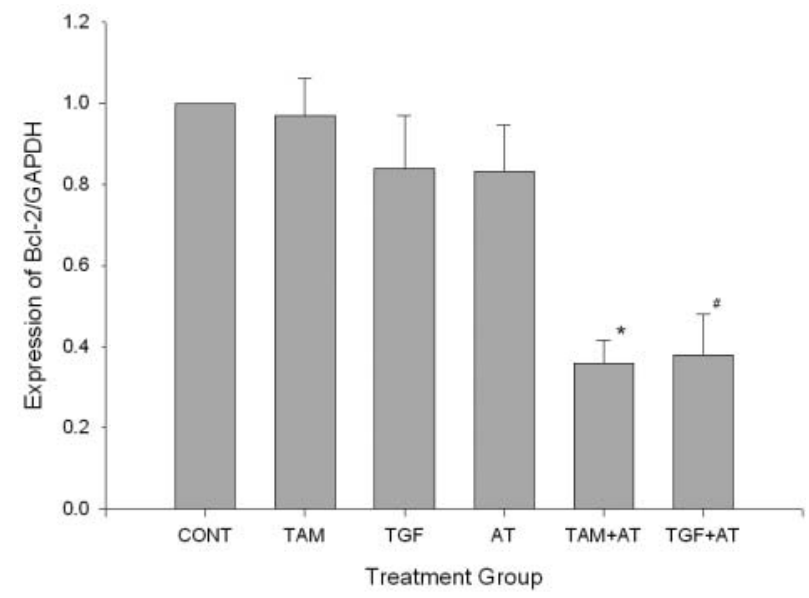

Figure 4 Modulation of $\mathrm{BCl}-2$ mRNA expression by TAM, AT, or TGF $\beta$. Cells were treated with vehicle (CONT) or AT $(1 \mu \mathrm{M})$, TAM (100 nM) and/or rhTGF 31 (TGF; $5 \mathrm{ng} / \mathrm{ml})$ for $72 \mathrm{~h}$, and Bcl-2 mRNA levels determined by quantitative RT-PCR as described in Materials and Methods. ${ }^{*} P<0.05$ vs CONT, AT, TAM; $\# P<0.05$ vs CONT, AT, TGF $\beta$.

To determine the specificity of the synergistic effect of TAM+AT for apoptosis, regulation of cell cycle progression and cell differentiation was studied. Treatment with TAM $(100 \mathrm{nM})$ alone or AT $(1 \mu \mathrm{M})$ alone each blocked cell cycle progression at $G_{0} G_{1}$, delaying entry into $S$ phase (Fig. 5). At this dose there was no additive or synergistic effect on cell cycle progression however, at either 4 days and 7 days of treatment. When the effect of TAM+AT on cellular epithelial membrane antigen (EMA) expression, an indicator of epithelial differentiation, was studied by immunoblot, no synergistic effect of the combination TAM+AT was seen on EMA expression at either 4 or 7 days of treatment (data not shown).

\section{Modulation of TGF $\beta$ by AT/TAM}

TGF $\beta$ is an autocrine regulator of cell growth in MCF-7 cells, and its secretion is stimulated by TAM (Perry et al. 1995, Chen et al. 1996, Knabbe et al. 2000). Regulation of TGF $\beta$ secretion by TAM+AT was studied using specific ELISAs to quantitate medium TGF $\beta$ content. Untreated cells secreted both TGF $\beta 1$ and TGF $\beta 2$ isomeric forms,

Figure 3 Modulation of $\mathrm{Bcl}-2$ protein expression by TAM, AT, or rhTGF $\beta 1$. Cells were treated with vehicle (CONT) or TAM $(100 \mathrm{nM})$ and/or AT $(1 \mu \mathrm{M})$ and/or rhTGF $\beta 1$ (5 ng/ml), and Bcl-2 protein or actin protein expression of cell lysates determined by immunoblot analysis at day 4 (top panel) and day 7 (bottom panel). (A) Protein expression for each treatment group was quantitated and is expressed in the histogram relative to control as described in Materials and Methods. (B) A representative immunoblot example for the respective histogram. (Top panel) ${ }^{*} P<0.01$ vs CONT. (Bottom panel) $\# P<0.05$ vs CONT; $+P<0.05$ vs CONT, AT, TAM; $\wedge P<0.05$ vs CONT, TGF $\beta$. 


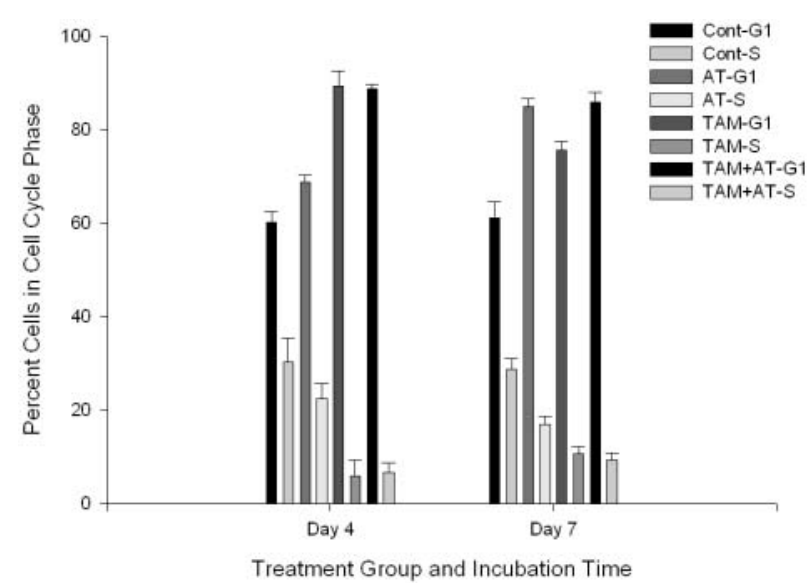

Figure 5 Regulation of cell cycle phase by TAM and AT. Cells were incubated with vehicle (Cont) or TAM (100 nM) and/or AT $(1 \mu \mathrm{M})$ and percent of cells in $\mathrm{G}_{0} \mathrm{G}_{1}$ or $\mathrm{S}$ phase determined at day 4 or day 7 by flow cytometry.

with a slight predominance of TGF $\beta 1$ (62.8\%; (Table 2)). The media of these studies were acid-activated prior to the TGF $\beta$ assay, and thus the TGF $\beta$ content which was measured was the total quantity secreted by these cells. TAM alone caused a significant increase in TGF $\beta 1$ secretion, and in combination TAM+AT had a marked synergistic effect on TGF $\beta 1$ secretion, increasing media levels five-fold over $72 \mathrm{~h}$ (Table 2), with a smaller but significant stimulation of TGF $\beta 2$ secretion.

Interaction of $A T$ and $T G F \beta$ to regulate growth and apoptosis of MCF-7 cells

The enhanced secretion of TGF $\beta$ by TAM+AT over $72 \mathrm{~h}$ preceeded the synergistic inhibition of growth at 5-7 days

Table 2 Stimulation of TGF $\beta 1$ and TGF $\beta 2$ secretion by TAM and AT. Cells were incubated with vehicle or TAM (100 nM) and/or AT $(1 \mu \mathrm{M})$ and the media content of acid-activated TGF $\beta 1$ or TGF $\beta 2$ determined by ELISA at $72 \mathrm{~h}$ as described in Materials and Methods. The concentrations of TGF $\beta 1$ and TGF $\beta 2$ are expressed as $\mathrm{pg} / 10^{6}$ cells per $72 \mathrm{~h}$ of the feeder monolayer

\begin{tabular}{|c|c|}
\hline & Media content \\
\hline \multicolumn{2}{|l|}{ TGF $\beta 1$} \\
\hline Control & $101 \cdot 1 \pm 17 \cdot 4$ \\
\hline AT & $124 \cdot 7 \pm 16 \cdot 2$ \\
\hline TAM & $232 \cdot 6 \pm 20 \cdot 6^{\#}$ \\
\hline TAM+AT & $493 \cdot 8 \pm 58 \cdot 4^{*}$ \\
\hline \multicolumn{2}{|l|}{ TGFß2 } \\
\hline Control & $59 \cdot 6 \pm 10 \cdot 9$ \\
\hline AT & $65 \cdot 3 \pm 12 \cdot 2$ \\
\hline TAM & $105 \cdot 4 \pm 19 \cdot 1$ \\
\hline $\mathrm{TAM}+\mathrm{AT}$ & $127 \cdot 7 \pm 20 \cdot 9^{+}$ \\
\hline
\end{tabular}

Journal of Endocrinology (2004) 183, 395-404

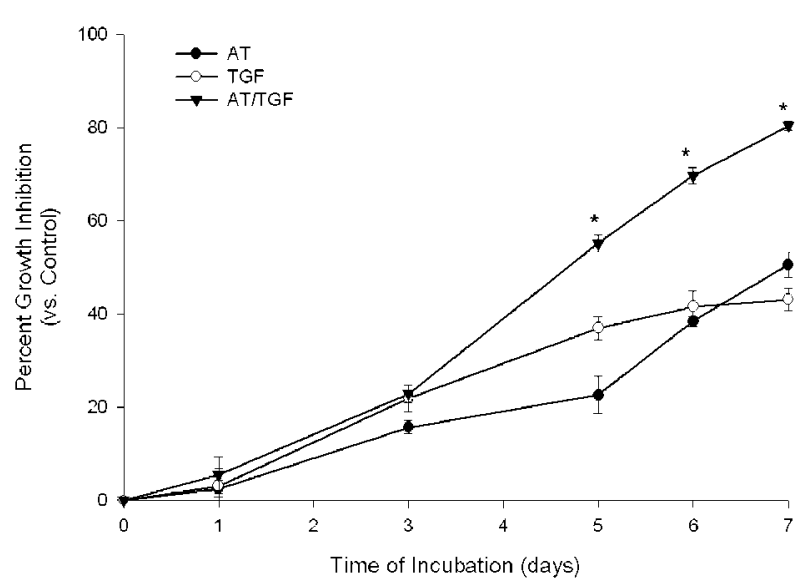

Figure 6 Effect of TGF $\beta 1$ and AT on MCF-7 cell growth. A monolayer of cells was incubated with vehicle or rhTGF $\beta 1$ (TGF; $5 \mathrm{ng} / \mathrm{ml})$ and/or AT $(1 \mu \mathrm{M})$ and cell numbers determined at the indicated time points. Cell growth is expressed as a percent of inhibition from control. ${ }^{*} P<0 \cdot 01$ vs TGF $\beta$ or $A T$, days $5,6,7$.

by TAM+AT, and TGF $\beta 1$ has been shown to interact with AT to inhibit cell growth (Valette \& Botanch 1990). When AT was studied in combination with TGF $\beta 1$, a synergistic inhibition of growth was observed which was time-dependent (Fig. 6) and dose-dependent for both AT (in the range of $10^{-6} \mathrm{M}$ to $10^{-8} \mathrm{M} ; \mathrm{P}<0 \cdot 01$ ) and for TGF $\beta 1$ (in the range of 0.05 to $5 \cdot 0 \mathrm{ng} / \mathrm{ml} ; P<0 \cdot 01$ ). When the effects of TGF $\beta$ on $\mathrm{Bcl}-2$ expression and apoptosis was studied, TGF $\beta+\mathrm{AT}$ was found to act synergistically to downregulate Bcl-2 mRNA expression at $72 \mathrm{~h}$ (Fig. 4), and Bcl-2 protein expression at 4 days and 7 days (Fig. 3). This was associated with a time-dependent synergistic stimulation of apoptosis by AT $+\mathrm{TGF} \beta$ at 7 days of treatment (Fig. 7).

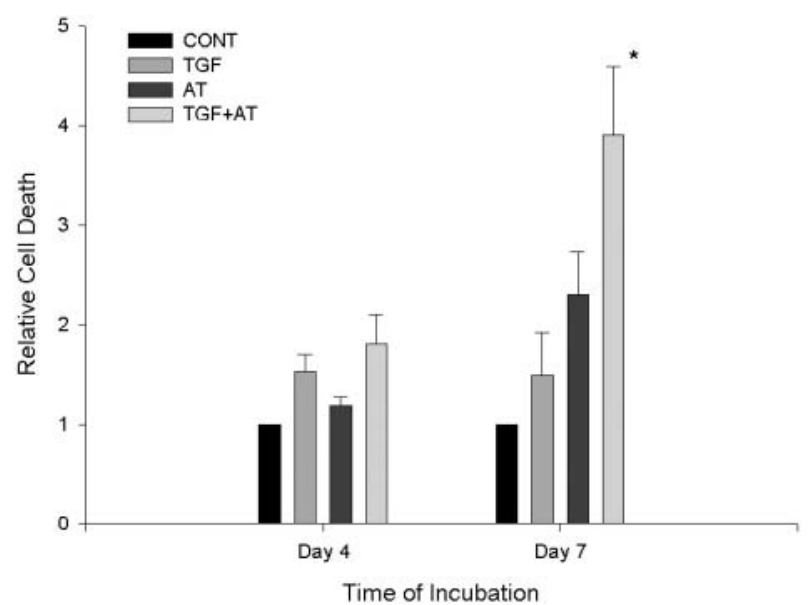

Figure 7 Regulation of apoptosis by TGF $\beta 1$ and AT. Cells were incubated with vehicle (CONT) or AT or rhTGF $\beta 1$ (TGF) as described in Fig. 6, and apoptosis measured on day 7 by DNA fragmentation ELISA. ${ }^{*} P<0 \cdot 05$ vs CONT, AT or TGF $\beta$, day 7 . 
These studies of AT, TAM, and TGF $\beta$ were conducted in media supplemented with unstripped calf serum. To clarify the effects of estradiol, the synergy of AT+TAM and AT+TGF was studied in charcoal-stripped calf serum supplemented with estradiol at concentrations ranging from 0.05 to $5.0 \mathrm{nM}$. Estradiol at 0.05 and $0.5 \mathrm{nM}$ did not suppress the synergistic effect of AT+TAM on cell growth $(P<0 \cdot 01)$; however, the synergistic effect of AT+TGF $\beta$
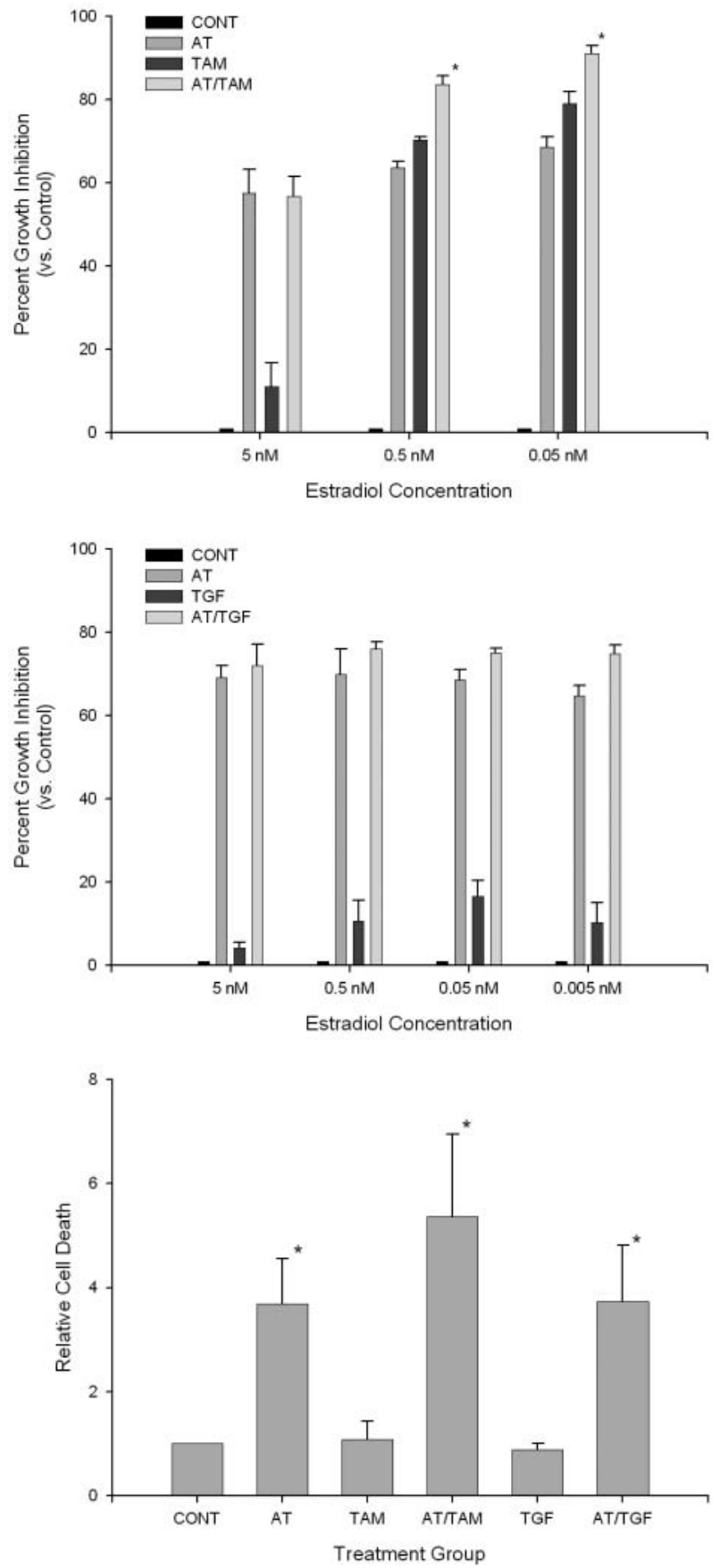

www.endocrinology-journals.org on cell growth was suppressed at all concentrations of estradiol, and a concentration of $0.5 \mathrm{nM}$ estradiol suppressed the synergistic stimulation of apoptosis for both AT+TAM and AT+TGF (Fig. 8).

To determine if TGF $\beta$ mediates TAM+AT synergism, cells were co-incubated with TAM+AT and neutralizing anti-TGF $\beta$ antibody, and $\mathrm{Bcl}-2$ protein expression were studied at 4 days and 7 days of treatment. TAM+AT downregulated $\mathrm{Bcl}-2$ protein expression, confirming the action of these two agents; however, this was not reversed at either of the two time points by anti-TGF $\beta$ antibody (Fig. 9). When the effect of the antibody on TAM+AT stimulation of apoptosis at 7 days was studied, no reversal of the apoptotic process was seen, consistent with the effects on Bcl-2 protein expression (Fig. 9).

\section{Discussion}

The ability of TAM and AT to act synergistically in combination to inhibit growth of breast cancer cells represents an important means for enhancing the antiproliferative effects of these two agents. The present report has demonstrated that the synergism of TAM+AT for growth inhibition was due to the selective stimulation of apoptosis. This is supported by the finding that TAM+AT acted synergistically to downregulate Bcl-2 mRNA and Bcl-2 protein expression, and to stimulate DNA fragmentation in a temporally related manner, without any additive or synergistic effect on cell cycle progression or cell differentiation. Downregulation of Bcl-2 is causally related to apoptosis in MCF-7 cells (Perillo et al. 2000), and the downregulation of mRNA levels is consistent with synergism occurring at the transcriptional level. These studies were conducted in media containing unstripped calf serum, and TAM and AT each have antiestrogenic properties, suggesting the possible involvement of estrogen in these effects. 17 $\beta$-Estradiol upregulates Bcl-2 transcription in MCF-7 cells, and binding of the ER to two cis-acting elements in the Bcl-2 coding region can result in an additive or synergistic stimulation of Bcl-2 gene expression (Perillo et al. 2000). Estradiol suppressed the synergistic stimulation of apoptosis by

Figure 8 Effect of estradiol on cell growth and apoptosis by TAM, $\mathrm{AT}$, and TGF $\beta 1$. Cells were incubated in phenol red-free media supplemented with charcoal-stripped calf serum. (top panel) Medium was supplemented with TAM $(100 \mathrm{nM})$ and/or AT $(1 \mu \mathrm{M})$ and the indicated concentrations of $17 \beta$-estradiol, and cell counts were determined at day $7\left({ }^{\star} P<0 \cdot 05\right.$ vs respective AT, TAM). (middle panel) Medium was supplemented with AT $(1 \mu \mathrm{M})$ and/or rhTGF $\beta 1$ (TGF; $5 \mathrm{ng} / \mathrm{ml}$ ) and the indicated concentrations of $17 \beta$-estradiol, and cell counts were determined at day 7 . (bottom panel) Medium was supplemented with TAM (100 nM) and/or AT $(1 \mu \mathrm{M})$ and/or rhTGF $\beta 1$ (TGF; $5 \mathrm{ng} / \mathrm{ml})$ and estradiol $(0.5 \mathrm{nM})$ and apoptosis measured at day 7 by DNA fragmentation ELISA as described in Materials and Methods. ${ }^{*} P<0.05$ vs control. 

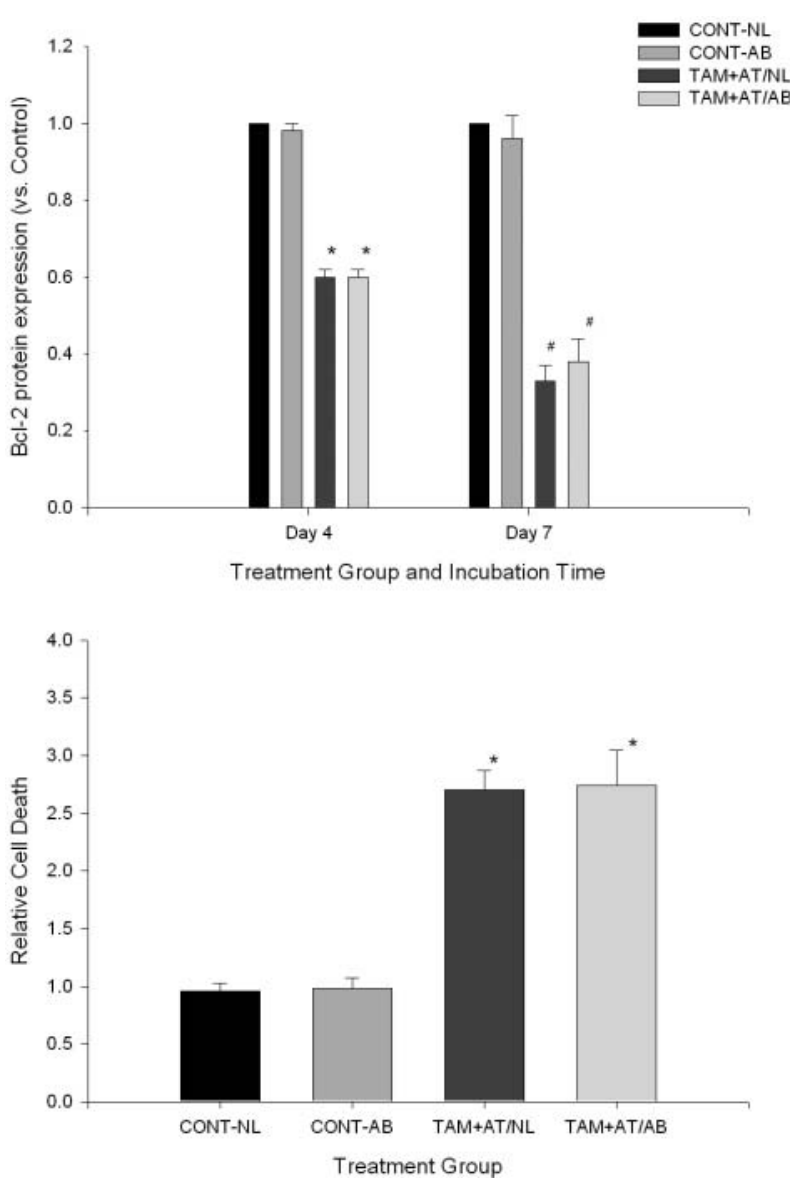

Figure 9 Effect of anti-TGF $\beta$ antibody on TAM+AT downregulation of $\mathrm{Bcl}-2$ protein and stimulation of apoptosis. Cells were incubated with vehicle (CONT) or TAM $(100 \mathrm{nM})+\mathrm{AT}(1 \mu \mathrm{M})$ and either anti-TGF $\beta$ antibody (AB) or normal IgG antibody (NL). (Top panel) $\mathrm{BCl}-2$ protein expression was determined by immunoblot analysis on day 4 and day 7 . ${ }^{*} P<0 \cdot 01$ vs CONT-NL, CONT-AB, day 4; $\# P<0 \cdot 01$ vs CONT-NL, CONT-AB, day 7. (Bottom panel) Apoptosis was measured on day 7 by DNA fragmentation ELISA, and values expressed as described in Fig. 2 . ${ }^{*} P<0 \cdot 01$ vs CONT-NL, CONT-AB.

TAM+AT, suggesting a potential role of the ER in regulating these effects.

The finding that $\mathrm{Bcl}-2$ plays an important role in the synergism of TAM+AT suggests a new convergence point for the action of these agents. Evidence has been presented by others that there are convergence points for retinoids and anti-estrogens in both the cell cycle pathway and the apoptotic pathway. Wilcken et al. (1996) studied the effects of AT and the anti-estrogen ICI 164,348 on human breast cancer cells (T47D) and found that both agents inhibited cell cycle progression in the $G_{1}$ phase. They found, however, that both AT and the anti-estrogen reduced the amount of hyperphosphorylated $\mathrm{pRb}$ within $48 \mathrm{~h}$, indicating that $\mathrm{pRb}$ was a point of convergence for the mechanism of action of AT and anti-estrogen. The present report expands these findings by indicating a second point of convergence for TAM and AT in the apoptotic pathway at the level of Bcl-2 mRNA and Bcl-2 protein. The Bcl-2 oncoprotein inhibits both cell cycle progression (Mazel et al. 1996) and apoptosis (Korsmeyer 1992), and can be modulated by exogenous substances (Wang \& Phang 1996). Bcl-2 is closely linked to $\mathrm{pRb}$, with overexpression of Bcl-2 blocking pRb dephosphorylation (Wang et al. 1996). The finding that TAM and AT downregulated $\mathrm{Bcl}-2$ provides a potential mechanism for reinforcing $\mathrm{pRb}$ dephosphorylation by these agents, further promoting inhibition of cell cycle progression. In addition, modulation of $\mathrm{Bcl}-2$ would indicate a convergence point for TAM and AT upstream to that of $\mathrm{pRb}$.

The possibility that $\mathrm{TAM}+\mathrm{AT}$ were acting in an indirect manner to stimulate apoptosis through regulation of TGF $\beta$ secretion was studied. TAM+AT acted synergistically to stimulate TGF $\beta$ secretion. TGF $\beta 1$ was the principle isomer secreted by these cells, and was the isomer whose secretion was most enhanced by TAM+AT. AT was found to act synergistically with TGF $\beta 1$ to inhibit growth, downregulate Bcl-2 mRNA and protein expression, and stimulate DNA fragmentation. This was temporally equivalent to that for TAM+AT, had a comparable dose-response relationship for AT, and involved comparable downregulation of $\mathrm{Bcl}-2$ protein and mRNA expression and stimulation of apoptosis. The synergism of TGF $\beta 1+$ AT on apoptosis was also suppressed by estradiol. Together, these findings suggested that TGF $\beta$ might be mediating the synergistic action of TAM+AT on apoptosis through its interaction with AT. Co-incubation of TAM+AT with anti-TGF $\beta$ antibody, however, did not block TAM+AT downregulation of Bcl-2 protein or block stimulation of apoptosis, indicating that the synergism of TAM+AT occurs independently of TGF $\beta$. The neutralizing antibody was shown to completely neutralize the concentration of active TGF $\beta$ in the media, and the antibody was present throughout the 7 days of incubation, providing sustained neutralizing capacity. The possibility that incomplete neutralization was because the antibody could not gain access to all of the TGF $\beta$, such as if some were sequestered between the cells and the culture dish as proposed by Tobin et al. (2001) for other studies, thus seems unlikely. Studies from this laboratory have shown that approximately $75 \%$ of TGF $\beta$ secreted by these MCF-7 cells is in the latent form and 25\% in the active form (Danforth \& Sgagias 1996). The degree to which the latent form might interfere with neutralization of the endogenous active form by the neutralizing antibody is not known. This possibility notwithstanding, the findings indicate that two parallel anti-proliferative processes, $\mathrm{TAM}+\mathrm{AT}$ and TGF $\beta 1+\mathrm{AT}$, are in effect and act without apparent cross-over. The mechanism of synergism for each remains to be defined; however, $\mathrm{Bcl}-2$ transcription will be an important focal point for future studies. 
In conclusion, $\mathrm{TAM}+\mathrm{AT}$ and $\mathrm{TGF} \beta+\mathrm{AT}$ represent two important means for enhancing growth inhibition of breast cancer cells. AT may allow increased efficacy of TAM, a widely used agent in the prevention and management of breast cancer. Both AT and TGF $\beta$ are naturally occurring agents, TGF $\beta$ is secreted by a variety of cell types including both epithelial and stromal breast cancer cells, and plasma levels of both substances have been well documented in breast cancer patients. The synergism between AT and TGF $\beta 1$ represents an important anti-proliferative mechanism with the potential to inhibit breast cancer cell growth at the primary, local/ regional, or distant sites.

\section{Acknowledgement}

There is no conflict of interest that would prejudice the impartiality of this work.

\section{References}

Anzano MA, Byers SW, Smith JM, Peer CW, Mullen LT, Brown CC, Roberts AB \& Sporn MB 1994 Prevention of breast cancer in the rat with 9-cis-retinoic acid as a single agent and in combination with tamoxifen. Cancer Research 54 4614-4617.

Arteaga CL, Hurd SD, Winnier AR, Johnson MD, Fendly BM \& Forbes JT 1993 Anti-transforming growth factor (TGF)-beta antibodies inhibit breast cancer cell tumorigenicity and increase mouse spleen natural killer cell activity. Implications for a possible role of tumor cell/host TGF-beta interactions in human breast cancer progression. Journal of Clinical Investigation 92 2569-2576.

Berenbaum MC 1981 Criteria for analyzing interactions between biologically active agents. Advances in Cancer Research 35 269-335.

Butler WB \& Fontana JA 1992 Responses to retinoic acid of tamoxifen sensitive and resistant sublines of human breast cancer cell line MCF-7. Cancer Research 52 6164-6167.

Chen H, Tritton TR, Kenny N, Absher M \& Chiu JF 1996 Tamoxifen induces TGF-beta 1 activity and apoptosis of human MCF-7 breast cancer cells in vitro. Journal of Cellular Biochemistry $\mathbf{6 1}$ 9-17.

Coradini D, Biffi A, Pellizzaro C, Pirronello E \& Di Fronzo G 1997 Combined effect of tamoxifen or interferon-beta and 4-hydroxyphenylretinamide on the growth of breast cancer cell lines. Tumor Biology 18 22-29.

Danforth DN Jr \& Sgagias MK 1996 Tumor necrosis factor alpha enhances secretion of transforming growth factor beta2 in MCF-7 breast cancer cells. Clinical Cancer Research 2 827-835.

Early Breast Cancer Trialists' Collaborative Group 1992 Systemic treatment of early breast cancer by hormonal, cytotoxic, or immune therapy. 133 randomised trials involving 31,000 recurrences and 24,000 deaths among 75,000 women. Early Breast Cancer Trialists' Collaborative Group. Lancet 339 71-85.

Fisher B, Costantino JP, Wickerham DL, Redmond CK, Kavanah M, Cronin WM, Vogel V, Robidoux A, Dimitrov N, Atkins J, Daly M, Wieand S, Tan-Chiu E, Ford L \& Wolmark N 1998 Tamoxifen for prevention of breast cancer: report of the National Surgical Adjuvant Breast and Bowel Project P-1 Study. Journal of the National Cancer Institute 90 1371-1388.

Fontana JA 1987 Interaction of retinoids and tamoxifen on the inhibition of human mammary carcinoma cell proliferation. Experimental Cell Biology 55 136-144.
Hayflick L 1973 Subculturing human diploid fibroblast cultures. In Tissue Culture: Methods and Applications, pp 220-223. Eds PF Kruse Jr \& MK Patterson Jr. Ardmore, OK, USA: Academic Press.

Helseth E, Unsgaard G, Dalen A \& Vik R 1988 Effects of type beta transforming growth factor in combination with retinoic acid or tumor necrosis factor on proliferation of a human glioblastoma cell line and clonogenic cells from freshly resected human brain tumors. Cancer Immunology, Immunotherapy 26 273-279.

Hoosein NM, Brattain DE, McKnight MK, Childress KE, Chakrabarty S \& Brattain MG 1988 Comparison of the antiproliferative effects of transforming growth factor beta, $\mathrm{N}, \mathrm{N}$-dimethylformamide and retinoic acid on a human colon cancer cell line. Cancer Letters 40 219-232.

Jeyaseelan K, Ma D \& Armugam A 2001 Real-time detection of gene promoter activity: quantitation of toxin gene transcription. Nucleic Acids Research 29 E58.

Keane MM, Ettenberg SA, Lowrey GA, Russell EK \& Lipkowitz S 1996 Fas expression and function in normal and malignant breast cell lines. Cancer Research 56 4791-4798.

Knabbe C, Lippman ME, Wakefield LM, Flanders KC, Kasid A, Derynck R \& Dickson RB 1987 Evidence that transforming growth factor-beta is a hormonally regulated negative growth factor in human breast cancer cells. Cell 48 417-428.

Knabbe C, Zugmaier G, Schmahl M, Dietel M, Lippman ME \& Dickson RB 2000 Induction of transforming growth factor beta by the antiestrogens droloxifene, tamoxifen, and toremifene in MCF-7 cells. American Journal of Clinical Oncology 14 (Suppl) S20.

Ko Y, Banerji S, Liu Y, Li W, Liang J, Soule SD, Pauley RJ, Willson JK, Zborowska E \& Brattain MG 1998 Expression of transforming growth factor-beta receptor type II and tumorigenicity in human breast adenocarcinoma MCF-7 cells. Journal of Cellular Physiology 176 424-434.

Koga M \& Sutherland RL 1991 Retinoic acid acts synergistically with 1,25-dihydroxyvitamin D3 or antiestrogen to inhibit T-47D human breast cancer cell proliferation. Journal of Steroid Biochemistry and Molecular Biology 39 455-460.

Koli KM, Ramsey TT, Ko Y, Dugger TC, Brattain MG \& Arteaga CL 1997 Blockade of transforming growth factor-beta signaling does not abrogate antiestrogen-induced growth inhibition of human breast carcinoma cells. Journal of Biological Chemistry 272 8296-8302.

Korsmeyer SJ 1992 Bcl-2 initiates a new category of oncogenes: regulator of cell death. Blood 80 879-886.

Liu Y, Lee M, Wang H, Li Y, Hashimoto Y, Klaus M, Reed JC \& Zhang X 1996 Retinoic acid receptor a mediates the growth inhibitory effect of retinoic acid by promoting apoptosis in human breast cancer cells. Molecular and Cellular Biology 16 1138-1149.

Marth C, Mayer I \& Daxenbichler G 1984 Effect of retinoic acid and 4-hydroxytamoxifen on human breast cancer cell lines. Biochemical Pharmacology 33 2217-2221.

Mazel S, Burtrum D \& Petrie HT 1996 Regulation of cell division cycle progression by bcl-2 expression: a potential mechanism for inhibition of programmed cell death. Journal of Experimental Medicine 83 2219-2226.

Perillo B, Sasso A, Abbondanza C \& Palumbo G 200017 beta-estradiol inhibits apoptosis in MCF-7 cells, inducing bcl-2 expression via two estrogen-responsive elements present in the coding sequence. Molecular and Cellular Biology 20 2890-2901.

Perry RR, Kang Y \& Greaves BR 1995 Relationship between tamoxifen-induced transforming growth factor beta 1 expression, cytostasis and apoptosis in human breast cancer cells. British Journal of Cancer 72 1441-1446.

Ratko TA, Detrisac CJ, Dinger NM, Thomas CF, Kelloff GJ \& Moon RC 1989 Chemopreventive efficacy of combined retinoid and tamoxifen treatment following surgical excision of a primary mammary cancer in female rats. Cancer Research 49 4472-4476.

Tobin SW, Brown MK, Douville K, Payne DC, Eastman A \& Arrick BA 2001 Inhibition of transforming growth factor beta signaling in 
MCF-7 cells results in resistance to tumor necrosis factor alpha: a role for Bcl-2. Cell Growth and Differentiation 12 109-117.

Toma S, Isnardi L, Raffo P, Dastoli G, DeFrancisci E, Riccardi L, Palumbo R \& Bollag W 1997 Effects of all trans retinoic acid and 13-cis-retinoic acid on breast cancer cell lines: growth inhibition and apoptosis induction. International Journal of Cancer 70 619-627.

Tong PS, Horowitz NN \& Wheeler LA 1990 Trans retinoic acid enhances the growth response of epidermal keratinocytes to epidermal growth factor and transforming growth factor beta. Journal of Investigative Dermatology 94 126-131.

Valette A \& Botanch C 1990 Transforming growth factor beta (TGF-beta) potentiates the inhibitory effect of retinoic acid on human breast carcinoma (MCF-7) cell proliferation. Growth Factors $2283-287$.

Wang H, Grand RJ, Milner AE, Armitage RJ, Gordon J \& Gregory CD 1996 Repression of apoptosis in human B-lymphoma cells by CD40-ligand and Bcl-2: relationship to the cell-cycle and role of the retinoblastoma protein. Oncogene 13 373-379.

Wang TT \& Phang JM 1995 Effects of estrogen on apoptotic pathways in human breast cancer cell line MCF-7. Cancer Research $552487-2489$.
Wang TT \& Phang JM 1996 Effect of N-(4-hydroxyphenyl)retinamide on apoptosis in human breast cancer cells. Cancer Letters 107 65-71.

Wetherall NT \& Taylor CM 1986 The effects of retinoid treatment and antiestrogens on the growth of T47D human breast cancer cells. European Journal of Cancer and Clinical Oncology 22 53-59.

Wilcken NR, Sarcevic B, Musgrove EA \& Sutherland RL 1996 Differential effects of retinoids and antiestrogens on cell cycle progression and cell cycle regulatory genes in human breast cancer cells. Cell Growth and Differentiation 7 65-74.

Wu G, Fan RS, Li W, Srinivas V \& Brattain MG 1998 Regulation of transforming growth factor-beta type II receptor expression in human breast cancer MCF-7 cells by vitamin D3 and its analogues. Journal of Biological Chemistry 273 7749-7756.

Zhang GJ, Kimijima I, Onda M, Kanno M, Sato H, Watanabe T, Tsuchiya A, Abe R \& Takenoshita S 1999 Tamoxifen-induced apoptosis in breast cancer cells relates to down-regulation of bcl-2, but not bax and bcl-X(L), without alteration of p53 protein levels. Clinical Cancer Research 5 2971-2977.

Received in final form 12 July 2004

Accepted 6 August 2004 